\title{
SISTEM INFORMASI PENJUALAN PADA CV. DISTRIBUSINDO BINTANG
}

\author{
Syakban ${ }^{1 *}$ \\ ${ }^{1}$ Program Studi Manajemen Informatika, Fakultas Ilmu Komputer, \\ AMIK Indonesia, Jl. T Nyak Arief Sp Mesra No. 400, Kota Banda Aceh, Indonesia \\ Email: syakban02@gmail.com ${ }^{1 *}$
}

\begin{abstract}
Abstrak
Tujuan dari penelitian ini adalah; 1) Untuk mengetahui Sistem Informasi Penjualan Pada CV. Distribusindo Bintang, 2) Untuk merancang Sistem Informasi Penjualan Pada CV. Distribusindo Bintang berbasis web. Dalam pembuatan model ini peneliti menyusun menggunakan diagram alir data yang merupakan alat perancangan sistem, sedangkan pada proses pengembangan prototipe menggunakan metode waterfall. Berdasarkan hasil peneltian maka penulis dapat menarik suatu kesimpulan yang diantaranya adalah sebagai berikut; 1) Penggunaan Sistem Informasi Penjualan pada CV. Distribusindo Bintang diharapkan dapat membantu membuat data Informasi Penjualan yang akurat dan efektif, 2) Dengan adanya sistem informasi memberikan kemudahan bagi CV. Distribusindo Bintang karena mempercepat informasi secara umum serta mengurangi kesalahan, dan 3) Sistem Informasi Penjualan pada CV. Distribusindo Bintang yang penulis rancang menggunakan berbagai bahasa pemrograman berbasis web yang terdiri dari; HTML, CSS, Jquery, Java Script, JSON PHP, dan untuk pengolahan database yang digunakan adalah bahasa Structure Query Language (SQLL). Untuk perangkat lunak pendukung yang digunakan adalah XAMPP versi 5.6 (Support MySQLi), NotePad ++, dan Browser Google Chrome.
\end{abstract}

Kata Kunci: Sistem Informasi; Penjualan; CV. Distribusindo Bintang.

\begin{abstract}
The aim of this research is; 1) To find out the Sales Information System on CV. Distribusi Bintang, 2) To design a Sales Information System at CV. Distribution of web-based Bintang. In making this model the researchers compiled using a data flow diagram which is a system design tool, while in the prototype development process using the waterfall method. Based on the results of the research, the author can draw a conclusion which includes the following; 1) Use of Sales Information System on CV. Distribusi Bintang is expected to help create accurate and effective Sales Information data, 2) With the information system, it is easy for CV. Distribution of Bintang for speeding up information in general and reducing errors, and 3) Sales Information System on CV. Distribusi Bintang which the author designed uses various web-based programming languages consisting of; HTML, CSS, Jquery, JavaScript, JSON PHP, and for database processing the Structure Query Language (SQL) is used. The supporting software used is XAMPP version 5.6 (Support MySQLi), NotePad ++, and Google Chrome Browser.
\end{abstract}

Keyword: Information Systems; Sale; CV. Distribusindo Bintang. 


\section{Pendahuluan}

Beberapa tahun terakhir ini perkembangan teknologi informasi berjalan sangat pesat, sehingga mengubah paradigma masyarakat dalam mencari sumber informasi yang sekarang tidak lagi terbatas pada informasi media cetak, radio, dan televisi, tetapi juga melalui koneksi internet [1]. Melalui internet kita bisa bertukar informasi dengan siapa saja, kapanpun kita mau dan dimanapun kita berada [2]. Dengan dampak yang seperti ini, banyak aspek yang terkena dampaknya, salah satunya dunia perdagangan. Perdagangan secara konvensional mengharuskan penjual bertemu dengan pembeli dalam suatu tempat dan melakukan transaksi jual beli di tempat tersebut [3]. Dengan perkembangan teknologi saat ini, cara lama seperti itu mulai ditinggalkan [4,5]. Inovasi di dalam dunia perdagangan telah bermunculan, salah satunya adalah e-commerce [6,7]. Dengan adanya e-commerce kita dapat melakukan transaksi jual beli dengan lebih mudah karena transaksi jual beli kita secara online dan tidak terbatas oleh tempat $[8,9]$.

Produk yang penulis pilih untuk menjadi komoditi e-comerce ini adalah produk rumah tangga. Produk rumah tangga adalah salah satu barang yang dibutuhkan serta mengalami perkembangan yang sangat cepat di era globalisasi ini. Berbagai macam seri keluaran baru dari setiap pabrikan produk rumah tangga setiap harinya bertarung di pasaran untuk berebut konsumen. Produsen produk rumah tangga saling menonjolkan fitur dan teknologi mereka masing-masing dan berlomba untuk memperoleh pangsa pasar yang besar. Antusias masyarakat juga sangat tinggi terhadap keluaran-keluaran terbaru dari setiap pabrikan produk rumah tangga tersebut. Antusiasme masyarakat tersebut tampak terlihat dari ramainya pusat-pusat penjualan produk rumah tangga dan banyaknya counter maupun distributor produk rumah tangga baru bermunculan. Dengan ketatnya persaingan pasar antar pedagang dan distributor, e-comerce merupakan alternatif untuk menjawab tantangan pasar. Adapun tujuan dari penelitian ini adalah; 1) Untuk mengetahui Sistem Informasi Penjualan Pada CV. Distribusindo Bintang, 2) Untuk merancang Sistem Informasi Penjualan Pada CV. Distribusindo Bintang berbasis web.

Aplikasi nantinya akan melibatkan berbagai bahasa pemrograman berbasis web, pemilihan bahasa pemrograman dan hasil rancangan secara online nantinya akan memudahkan pengguna aplikasi dalam melakukan monitoring setiap saat $[10,11]$. Keuntungan lain menggunakan aplikasi web adalah bersifat multiplatform atau dapat digunakan dari semua gadget [12]. Mulai dari komputer, tablet, hingga smartphone. Hal ini tentu saja memudahkan pengguna untuk memiliki akses yang fleksibel sehingga produktivitas pekerjaan tidak terganggu $[13,14]$.

\section{Metode Penelitian}

Dalam pembuatan model ini peneliti menyusun menggunakan diagram alir data yang merupakan alat perancangan sistem yang berorientasi pada alur data dengan konsep dekomposisi serta digunakan untuk penggambaran analisa maupun rancangan sistem yang mudah dikomunikasikan oleh profesional sistem kepada pemakai maupun pengembang $[15,16]$. Sedangkan pada proses pengembangan prototipe menggunakan metode waterfall. $[17,18,19]$. Proses pengolahan data penjualan pada CV. Distribusindo Bintang pada dasarnya sangat berbeda jauh dengan sistem lama, yang membedakannya adalah media dan peralatan yang dipakainya. Dalam penginputan datadata penjualan dan data lainnya, sistem rancangan baru yang menggunakan sebuah aplikasi komputerisasi. Cara kinerja sistem yang memperoleh hasil pengimputan data yang tertera pada sebuah file. Agar lebih jelasnya rancangan sistem baru dapat dilihat pada gambar berikut: 


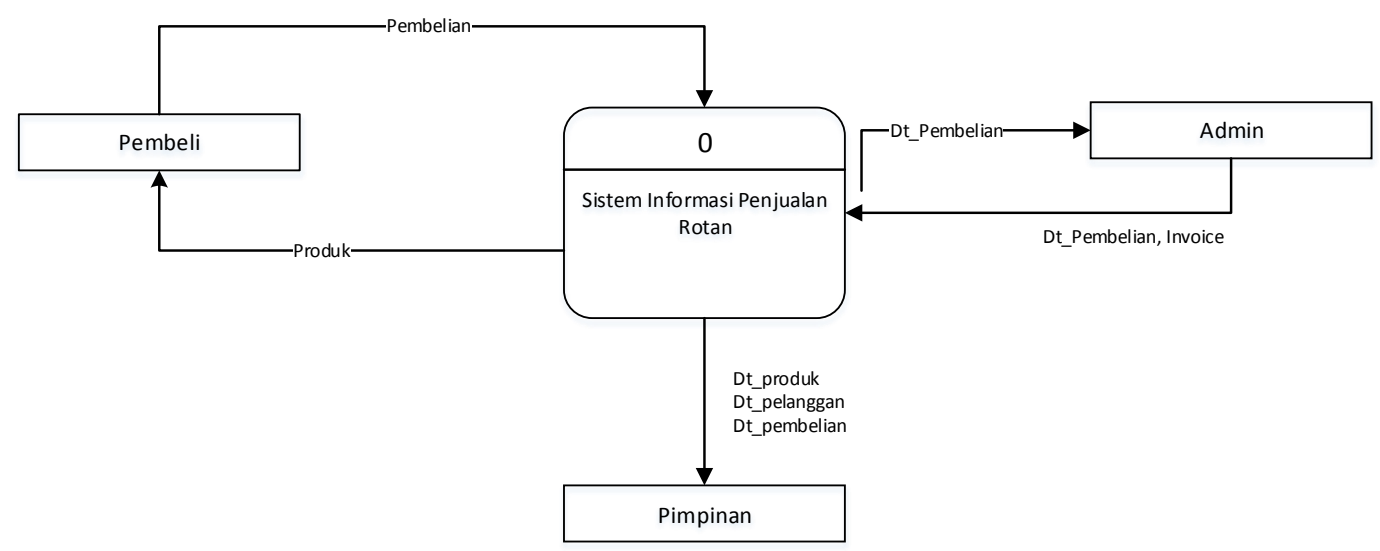

Gambar 1. Diagram Konteks Sistem Rancangan

Dari gambar 1, diatas jelas bahwa pada Diagram Konteks Sistem Rancangan, berawal dari admin menginput data kategori, data produk, dan data blog, selanjutnya pembeli menginput data biodata dan mengisi transaksi pembelian, setelah semua data tersebut diproses, maka file hasil rekap pembelian tersebut dikirim ke Pimpinan, setelah itu sistem memberikan rekap transaksi penjualan keseluruhan. Kemudian data-data yang sudah tersimpan pada file masing-masing akan diproses pada proses pembuatan laporan dimana hasil dari laporan tersebut akan diserahkan kepada Pimpinan. Agar lebih jelasnya diagaram berjenjang sistem rancangan baru dapat dilihat pada gambar berikut:

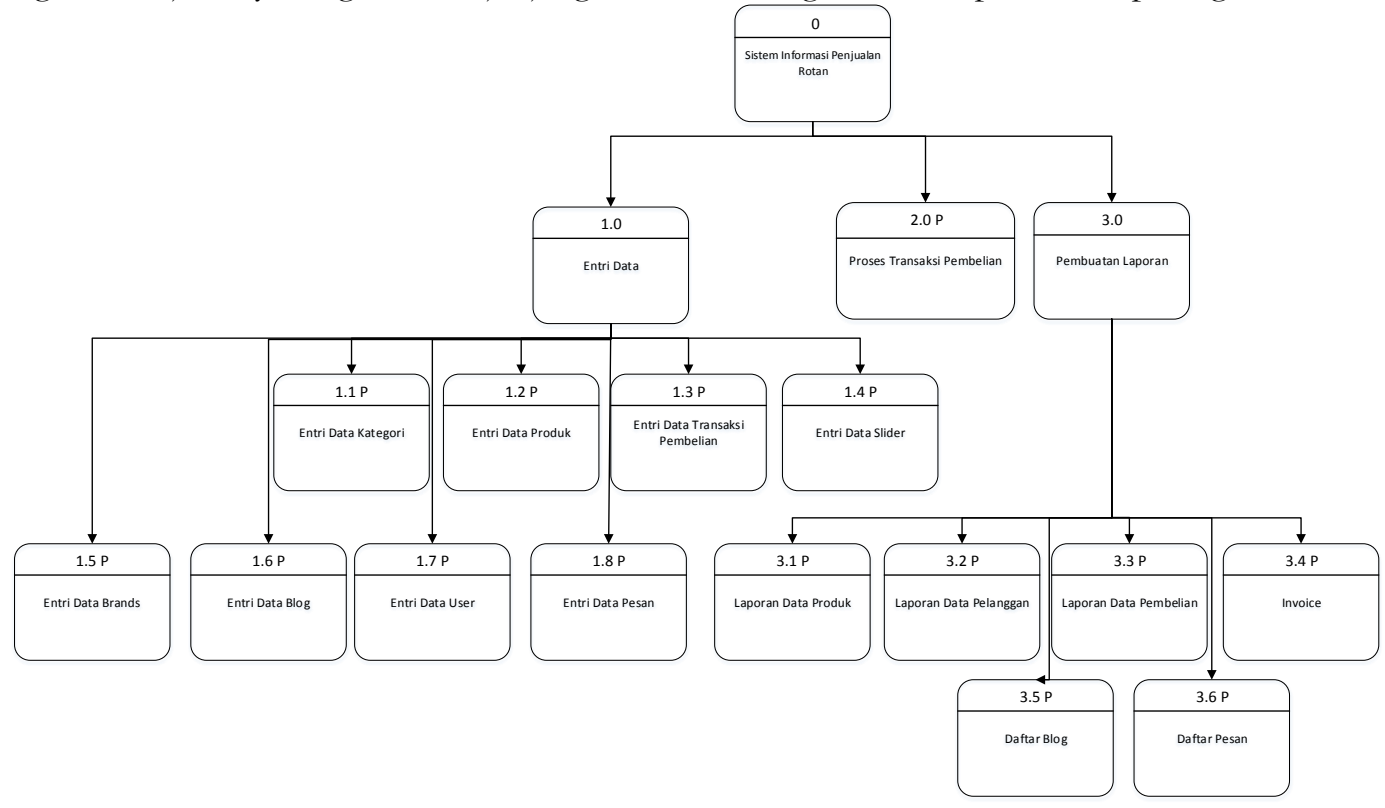

Gambar 2. Diagram Berjenjang Sistem Rancangan

Berdasarkan gambar 2, diatas terlihat bahwa Pada Diagram berjenjang Sistem Rancangan di atas terdiri dari tiga proses yaitu proses Entry data, proses transaksi pembelian dan pembuatan laporan. Pada entri data terdapat delapan sub sistem sedangkan pada proses pembuatan laporan terdiri dari enam buah sub sistem. 


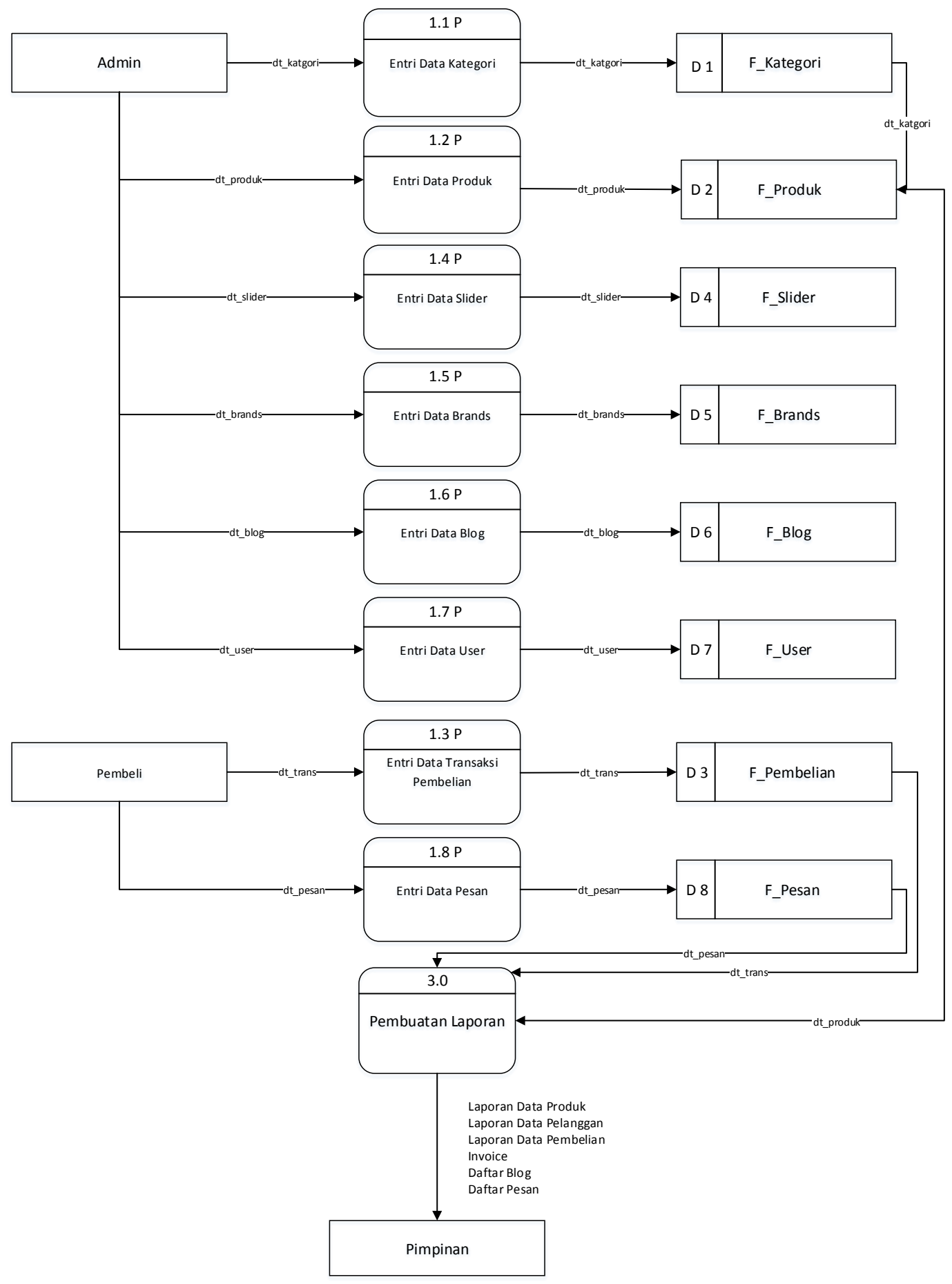

Gambar 3. Rancangan Diagram arus data level 0 Sistem Rancangan

Berdasarkan gambar 3, Pada Diagram Arus Data Level 0 Sistem Rancangan, Berawal dari Admin mengimput data, dimana data tersebut tersimpan pada file masing, setalah itu pembeli menginput data pembelian, dimana kesemua data tersebut akan menghasilkan transaksi pembelian untuk direkam menjadi beberapa file, dimana file tersebut akan menjadi laporan yang akan diserahakan kepada pimpinan. Untuk lebih jelas tentang proses rancangan penjualan di CV. 
Distribusindo Bintang dapat di jelaskan pada diagram arus data level 1 proses no 1 sistem rancangan.

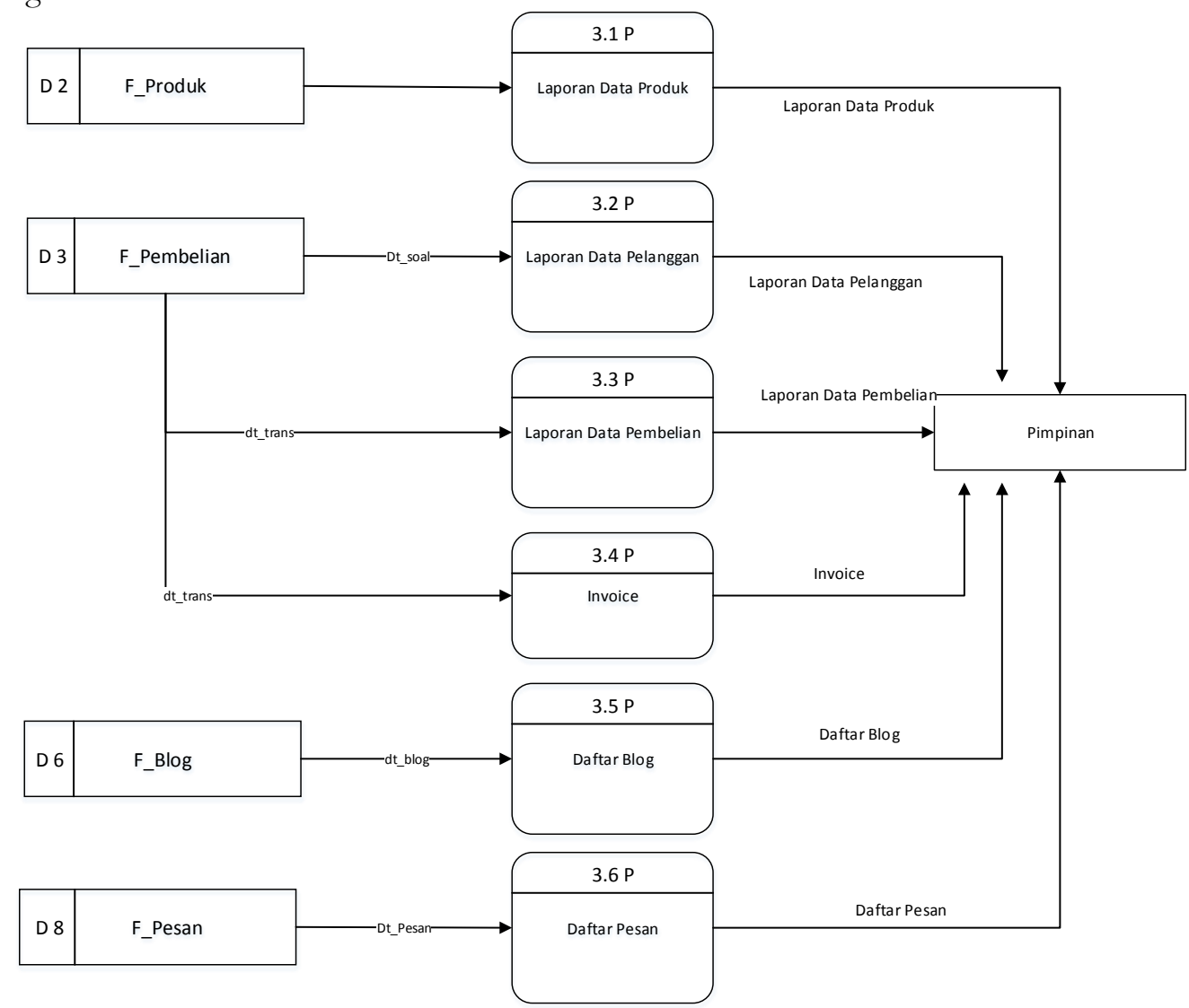

Gambar 4. Diagram Arus Data Level 1 Proses No 1 Sistem Rancangan

Berdasarkan Gambar 4, Diagram Arus Data Level 1 Proses No. 1 Sistem Rancangan diatas terdiri dari enam proses. Selanjutnya data-data tersebut direkam dan tersimpan pada file datastore masing-masing untuk diproses pada proses selajutnya. Untuk desain struktur data terdiri dari struktur data admin, pelanggan, order, order item, produk, berita, brands, pesan, kategori, slider, dan setting.

Tabel 1. Struktur Data Admin

\begin{tabular}{|c|c|c|c|c|}
\hline No & Nama Field & Type Data & Size & Keterangan \\
\hline 1 & Id_admin & Int & 4 & Primary Key \\
\hline 2 & Nama & Varchar & 50 & - \\
\hline 3 & Username & Varchar & 20 & - \\
\hline 4 & Password & Varchar & 20 & \\
\hline 5 & Level & Varchar & 20 & \\
\hline 6 & Foto & Text & - & - \\
\hline
\end{tabular}

Tabel 2. Struktur Data Pelanggan

\begin{tabular}{|c|c|c|c|c|}
\hline No & Nama Field & Type Data & Size & Keterangan \\
\hline 1 & Customer_id & Int & 4 & Primary Key \\
\hline 2 & Name & Varchar & 50 & - \\
\hline 3 & Email & Varchar & 20 & - \\
\hline
\end{tabular}




\begin{tabular}{lllll}
\hline 4 & Phone & Varchar & 20 & - \\
5 & address & Varchar & 20 & - \\
6 & Created & Date & - & - \\
7 & Modified & Date & - & - \\
8 & status & Enum & 1 & - \\
9 & Negara & Varchar & 50 & - \\
10 & Provinsi & Varchar & 50 & - \\
11 & Kota & Varchar & 50 & - \\
12 & Kecamatan & Varchar & 50 & - \\
13 & Kode_pos & Varchar & 6 & - \\
\hline
\end{tabular}

Tabel 3. Struktur Data Orders

\begin{tabular}{|c|c|c|c|c|}
\hline No & Nama Field & Type Data & Size & Keterangan \\
\hline 1 & Order_id & Int & 4 & Primary Key \\
\hline 2 & Customer_id & Int & 4 & Foreign Key \\
\hline 3 & Total_price & Varchar & 20 & - \\
\hline 4 & Created & Date & - & - \\
\hline 5 & Modified & Date & - & - \\
\hline 6 & Status & Enum & 1 & - \\
\hline
\end{tabular}

Tabel 4. Struktur Data Orders Item

\begin{tabular}{|c|c|c|c|c|}
\hline No & Nama Field & Type Data & Size & Keterangan \\
\hline 1 & Order_id & Int & 4 & Primary Key \\
\hline 2 & Product_id & Int & 4 & Foreign Key \\
\hline 3 & Quantity & Int & 5 & - \\
\hline
\end{tabular}

Tabel 5. Struktur Data Products

\begin{tabular}{|c|c|c|c|c|}
\hline No & Nama Field & Type Data & Size & Keterangan \\
\hline 1 & Product_id & Int & 4 & Primary Key \\
\hline 2 & Name & Int & 4 & Foreign Key \\
\hline 3 & Description & Text & - & - \\
\hline 4 & Price & Varchar & 15 & - \\
\hline 5 & Created & Date & - & - \\
\hline 6 & Modified & Date & - & - \\
\hline 7 & Status & Enum & 1 & - \\
\hline 8 & Foto & Text & - & - \\
\hline 9 & Tag & Text & - & - \\
\hline 10 & Meta_title & Text & - & - \\
\hline 11 & Meta_keyword & Text & - & - \\
\hline 12 & Brand & Text & - & - \\
\hline 13 & Type & Text & - & - \\
\hline 14 & Slug & Text & - & - \\
\hline 15 & Avability & Text & - & - \\
\hline 16 & Kategori & Text & - & - \\
\hline
\end{tabular}


Tabel 6. Struktur Data Berita

\begin{tabular}{|c|c|c|c|c|}
\hline No & Nama Field & Type Data & Size & Keterangan \\
\hline 1 & Berita_ID & Int & 4 & Primary Key \\
\hline 2 & Judul_berita & Text & - & - \\
\hline 3 & Slug_berita & Text & - & - \\
\hline 4 & Content_berita & Text & - & - \\
\hline 5 & Tanggal_input & Date & - & - \\
\hline 6 & Foto & Text & - & - \\
\hline
\end{tabular}

Tabel 7. Struktur Data Brands

\begin{tabular}{|c|c|c|c|c|}
\hline No & Nama Field & Type Data & Size & Keterangan \\
\hline 1 & Brands_ID & Int & 4 & Primary Key \\
\hline 2 & Judul & Text & - & - \\
\hline 3 & Deskripsi & Text & - & - \\
\hline 4 & Tanggal_input & Date & - & - \\
\hline 5 & Foto & Text & - & - \\
\hline
\end{tabular}

Tabel 8. Struktur Data Pesan Masuk/ Inbox

\begin{tabular}{|c|c|c|c|c|}
\hline No & Nama Field & Type Data & Size & Keterangan \\
\hline 1 & Inbox_ID & Int & 4 & Primary Key \\
\hline 2 & Nama & Text & 20 & - \\
\hline 3 & Email & Text & 40 & - \\
\hline 4 & Subjek & Text & 50 & - \\
\hline 5 & Pesan & Text & - & - \\
\hline 6 & Tanggal & Date & - & - \\
\hline
\end{tabular}

Tabel 9. Struktur Data Kategori

\begin{tabular}{|c|c|c|c|c|}
\hline No & Nama Field & Type Data & Size & Keterangan \\
\hline 1 & Id_Kategori & Int & 4 & Primary Key \\
\hline 2 & Kategori & Text & 50 & - \\
\hline 3 & Tanggal & Date & - & - \\
\hline
\end{tabular}

Tabel 10. Struktur Data Slider

\begin{tabular}{|c|c|c|c|c|}
\hline No & Nama Field & Type Data & Size & Keterangan \\
\hline 1 & slider_ID & Int & 4 & Primary Key \\
\hline 2 & Judul & Text & 50 & - \\
\hline 3 & Deskripsi & Text & 50 & - \\
\hline 4 & Foto & Text & - & - \\
\hline 5 & tanggal_input & Date & - & - \\
\hline
\end{tabular}


Tabel 11. Struktur Data Settings

\begin{tabular}{|c|c|c|c|c|}
\hline No & Nama Field & Type Data & Size & Keterangan \\
\hline 1 & ID & Int & 4 & Primary Key \\
\hline 2 & TOR & Text & - & - \\
\hline 3 & Kebijakan dan Privasi & Text & - & - \\
\hline 4 & Layanan & Text & - & - \\
\hline 5 & Pengiriman & Text & - & - \\
\hline
\end{tabular}

\section{Hasil dan Pembahasan}

Adapun hasil rancangan Sistem Informasi Penjualan rotan di CV. Distribusindo Bintang Berbasis Website, sebagai berikut: Sedangkan tampilkan hasil rancangan aplikasi terlihat pada gambar 5 berikut ini:

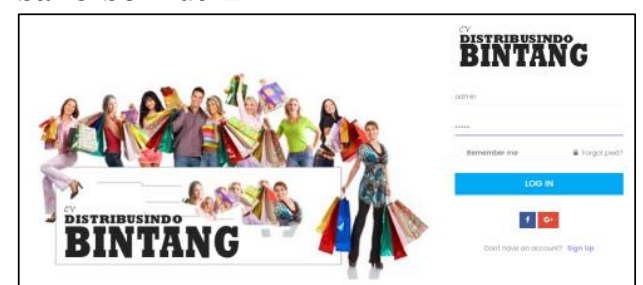

(a) Form Login

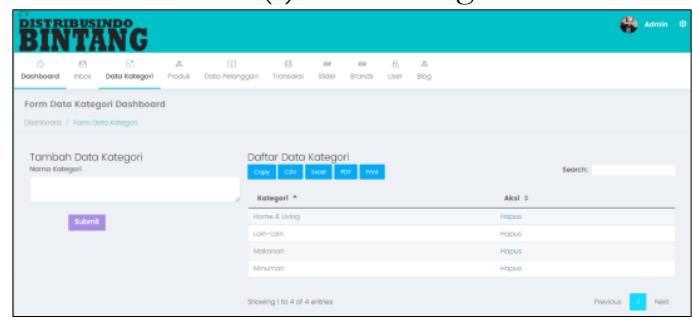

(c) Form Kategori

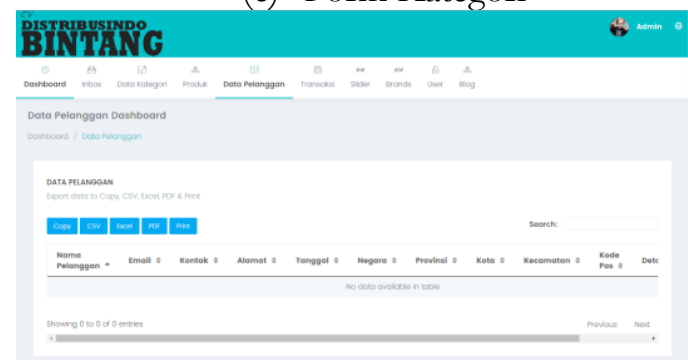

(e) Form Pelanggan

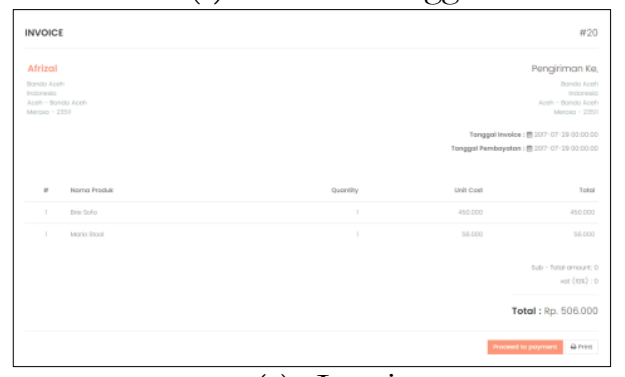

(g) Invoice

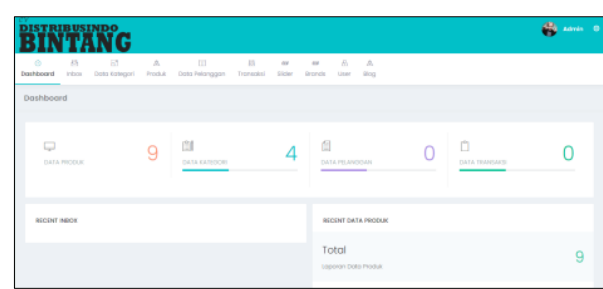

(b) Halaman Menu Utama

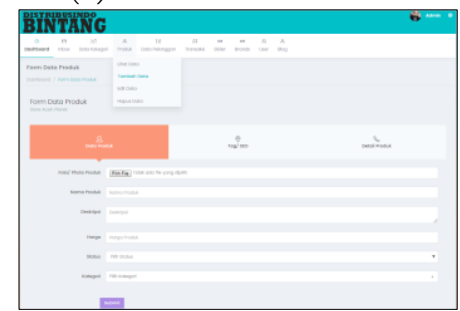

(d) Form Produk

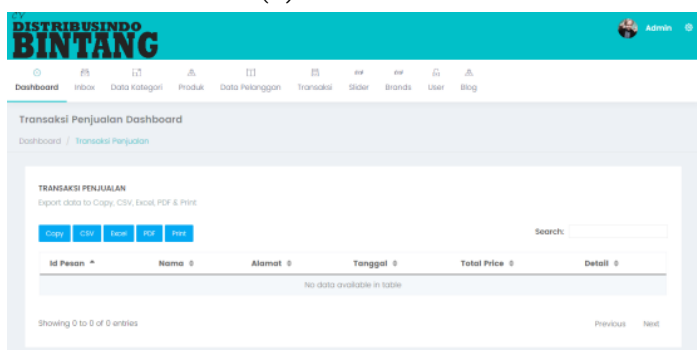

(f) Form Transaksi

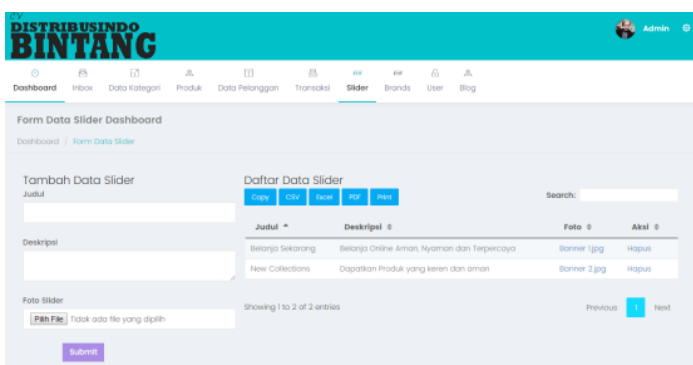

(h) Slider 


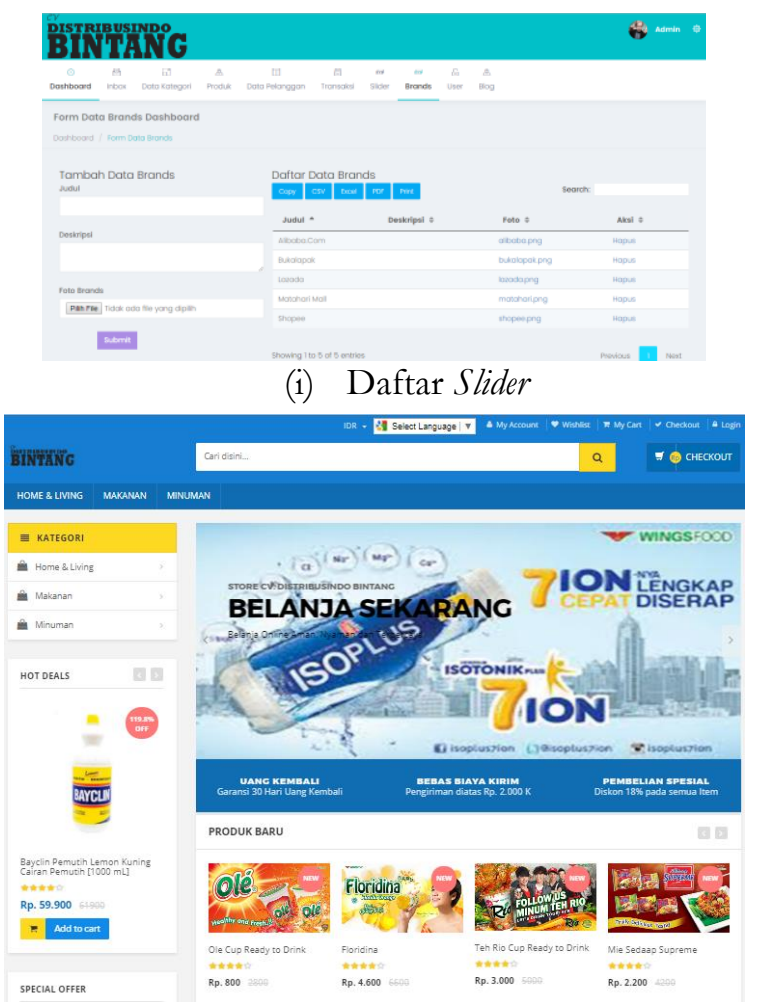

(k) Halaman Publik

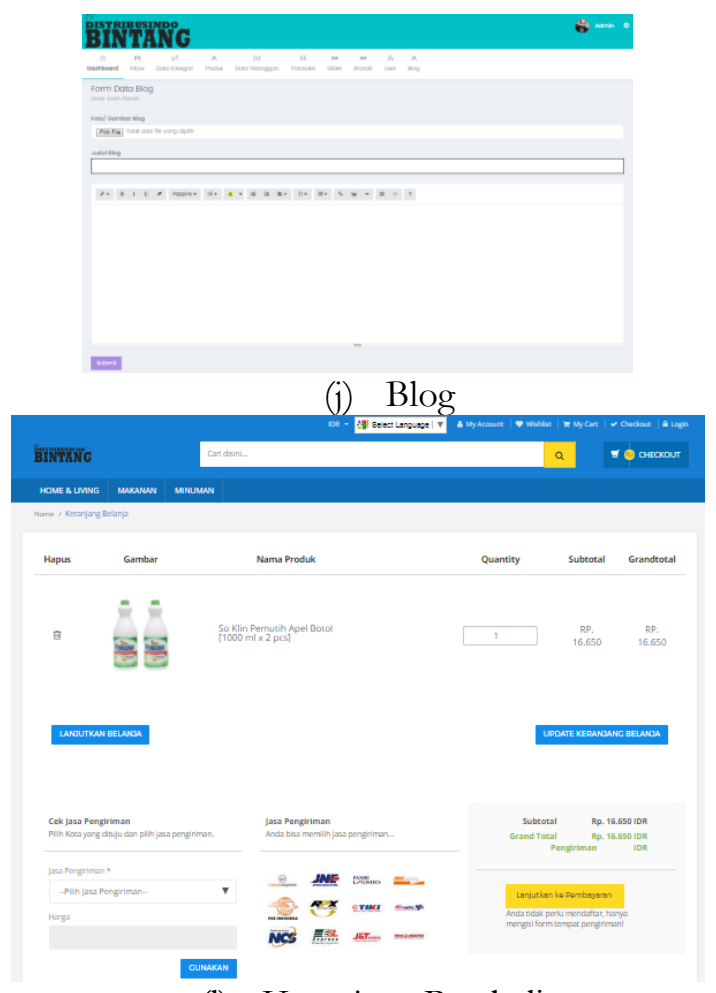

(l) Keranjang Pembelian

Gambar 5. Hasil Rancangan

\section{Kesimpulan dan Saran}

Berdasarkan hasil pengamatan dan penulis dapat menarik suatu kesimpulan yang diantaranya adalah sebagai berikut :

1) Penggunaan Sistem Informasi Penjualan pada CV. Distribusindo Bintang diharapkan dapat membantu membuat data Informasi Penjualan yang akurat dan efektif.

2) Dengan adanya sistem informasi memberikan kemudahan bagi CV. Distribusindo Bintang karena mempercepat informasi secara umum serta mengurangi kesalahan.

3) Sistem Informasi Penjualan pada CV. Distribusindo Bintang yang penulis rancang menggunakan berbagai bahasa pemrograman berbasis web yang terdiri dari; HTML, CSS, Jquery, Java Script, JSON PHP, dan untuk pengolahan database yang digunakan adalah bahasa Structure Query Language (SQLL). Untuk perangkat lunak pendukung yang digunakan adalah XAMPP versi 5.6 (Support MySQLi), NotePad ++, dan Browser Google Chrome. berikut :

Adapun saran yang ingin penulis sampaikan setelah melakukan pengamatan adalah sebagai

1) Untuk dapat menghasilkan data yang akurat dengan tingkat kesalahan yang minim, pemanfaatan komputer harus lebih dioptimalkan salah satunya yaitu dengan tidak hanya terfokus pada microsoft office saja, akan tetapi penggunaan semua software yang ada akan dapat mengoptimalkan hasil pegolahan data.

2) Untuk mengoptimalkan penggunaan komputer diperlukan penambahan brainware sebagai orang yang akan berkomunikasi dengan komputer untuk menghasilkan hasil yang optimal. 


\section{Daftar Pustaka}

[1] Mulyono, I.U.W., Rachmawanto, E.H., Susanto, A., Sari, C.A., Prabowo, D.P. and Ihya'Ulumuddin, D.I., 2020. Implementasi E-Learning Menggunakan Edmodo bagi GuruGuru SD Kecamatan Cawas, Klaten. ABDIMASKU: Jurnal Pengabdian Masyarakat, 3(1), pp.56-64.

[2] Wali, M., Sudaryanto, A., Utami, U., Fimawahib, L. and Rizal, S., 2021. PENDAMPINGAN PEMANFAATAN FACEBOOK BUSINESS SUITE SEBAGAI UPAYA PENINGKATAN PENJUALAN PADA USAHA BAKERY. at-tamkin: Jurnal Pengabdian kepada Masyarakat, 4(2), pp.36-43.

[3] Wali, M., Iqbal, T. and Syafwandhinata, J., 2021. IbM Pelatihan, Pembinaan dan Pendampingan Penggunaan Aplikasi Management Stock Control. AJAD: Jurnal Pengabdian kepada Masyarakat, 1(1), pp.9-16.

[4] Syamsuar, S. and Reflianto, R., 2019. Pendidikan dan tantangan pembelajaran berbasis teknologi informasi di era revolusi industri 4.0. E-Tech: Jurnal Ilmiah Teknologi Pendidikan, 6(2).

[5] Setiawan, M.A.B., 2017. Policy of Information and Communication Technologies to Promote the Formation of Future Business Models (Kebijakan Teknologi Informasi dan Komunikasi Untuk Mendorong Pembentukan Model Bisnis Masa Depan). Pekommas, 2(2), p.222366.

[6] Wali, M., 2019. Application Optimizing the Placement of Safety Stocks Using the Max-Min Method for Printing Companies. International Journal of Research and Review, 6(2), pp.203-210.

[7] Syarif, M. and Nugraha, W., 2020. Pemodelan Diagram UML Sistem Pembayaran Tunai Pada Transaksi E-Commerce. JTIK (Jurnal Teknik Informatika Kaputama), 4(1), pp.64-70.

[8] Tarmizi, T. and Ismail, I., 2020. Model Marketplace Berbasis Kearifan Lokal. Jurnal EMT KITA, 4(1), pp.11-18.

[9] Putra, W.A., Fitri, I. and Hidayatullah, D., 2022. Implementasi Waterfall dan Agile dalam Perancangan E-Commerce Alat Musik Berbasis Website. Jurnal JTIK (Jurnal Teknologi Informasi dan Komunikasi), 6(1), pp.56-62.

[10] Wali, M., 2017. Membangun Aplikasi Windows dengan Visual Basic. NET 2015 Teori dan Praktikum: Indonesia (Vol. 1). KITA Publisher.

[11] Wali, M., Ahmad, L., Akbar, R., Salam, A. and Ismail, I., 2020. Source Code Library (SCL): Software Development Learning Application. International Journal of Scientific \& Technology Research, 9(2), pp.175-182. 
[12] Wali, M. and Ahmad, L., 2018. Perancangan Access Open Journal System (AOJS) dengan menggunakan Framework Codeigniter dan ReactJs. Jurnal JTIK Jurnal Teknologi Informasi dan Komunikasi), 2(1), pp.48-56.

[13] Satria, D., Yana, S., Munadi, R. and Syahreza, S., 2017. Sistem peringatan dini banjir secara real-time berbasis web menggunakan arduino dan ethernet. Jurnal JTIK Jurnal Teknologi Informasi dan Komunikasi), 1(1), pp.1-6.

[14] Yauma, A., Fitri, I. and Ningsih, S., 2021. Learning Management System (LMS) pada ELearning Menggunakan Metode Agile dan Waterfall berbasis Website. Jurnal JTIK (Jurnal Teknologi Informasi dan Komunikasi), 5(3), pp.323-328.

[15] Adrianto, L.B., Wahyuddin, M.I. and Winarsih, W., 2021. Implementasi Deep Learning untuk Sistem Keamanan Data Pribadi Menggunakan Pengenalan Wajah dengan Metode Eigenface Berbasis Android. Jurnal JTIK (Jurnal Teknologi Informasi dan Komunikasi), 5(1), pp.89-96.

[16] Herlan, A., Fitri, I. and Nuraini, R., 2021. Rancang Bangun Sistem Monitoring Data Sebaran Covid-19 Secara Real-Time menggunakan Arduino Berbasis Internet of Things (IoT). Jurnal JTIK (Jumal Teknologi Informasi dan Komunikasi), 5(2), pp.206-212.

[17] Suhaimah, A., Triayudi, A. and Handayani, E.T.E., 2021. Cyber Library: Pengembangan Perpustakaan Online Berbasis Web Menggunakan Metode Prototyping (Studi Kasus Universitas Nasional). Jurnal JTIK (Jurnal Teknologi Informasi dan Komunikasi), 5(1), pp.41-48.

[18] Zulkhaida, K., Henryanto, Y. and Jaenuddin, H., 2021. Information Systems Inventory of Goods in The Warehouse at PT. Transvision. International Journal Software Engineering and Computer Science (IJSECS), 1(1), pp.7-12.

[19] Ardiansyah, A., Fitri, I. and Iskandar, A., 2021. Aplikasi Manajemen Perkantoran dan Absensi Online Berbasis Android. Jurnal JTIK (Jurnal Teknologi Informasi dan Komunikasi), 5(2), pp.126-134. 